\title{
Reaction Mechanism for the Hydrolysis of Titanium Alkoxides
}

\author{
Jin-Koo Park, Jung-Jae Myoung, ${ }^{\dagger}$ Jin-Burm Kyong, and Ho-Kun Kim ${ }^{\circ}$ \\ Deparment of Applied Chemisty. Hamang Lniversity, Ansan f25-79I, Norea \\ ${ }^{\dagger}$ Research Center, Dongwo tine-Chem, Hsam 570-1 to, Norea \\ Recerved Februany 20.2003
}

Key Words : $\Lambda$ ssociative mechanism. Guggenheim method, Bimolecular reaction, Titanium tetra ethoxide

Metal alkoxides have strong reacitivities duc to the difference of polari/abilitics between metal and alkoxy groups. Hence. many kinds of melal alkoxides can bc lydroly/ed with ease and transformed to metal oxide powder via a condensation-polymerization reaction of the lydroly/ed species. The hydrolysis reaction mechanisms of the metal alkoxides depend on the electron aflinitics. sizes and charges of metal ions and alkoxy groups. ${ }^{1-3}$ In the case of alkoxides that have the same metal ions. the sizes and numbers of alkoxy groups play an important role in the lwydrolysis reaction. Examples are found in silicon alkoxide where the reaction rates of hydrolysis decrease with increasing size of the alkoxy groups through sicric effects. ${ }^{1.5}$ Reaction rates or meclanisms of metal alkoxides can be also clanged by the kinds of metal ions. Particularly. the transition metal ions. which have different oxidation states. lave different electron affinitics. sizes and coordination numbers. so careful imestigation of the lydrolysis of transition metal alkoxides is required. ' The kinctic studics on the bydrolysis reactions of metal alkoxides. in general. have been carried oul by spectroscopic melhods ${ }^{6-x}$ such as NMR. Raman. Infrared. UV. cte. Extensive kinctic data for the silicon alkoxides $s^{9.11}$ have becn obtaincd by the above melhods. but very few kinctic results for the transition metal alkoxides lave been reponcd.

In this study. the lydrolysis reaction rate and mechanism of the titanium tetra elhoxide ( $\left.\mathrm{Ti}\left(\mathrm{OC}_{2} \mathrm{H}_{5}\right)_{4}\right)$ were imestigated by the use of the UV spectroscopic method and the results were compared with those of the other titanium alkoxides reported in our previous works. ${ }^{11-13}$

\section{Experimental Section}

$4.5 \times 10^{3} \mathrm{M}$ titanium tetra clloxide $\left[\mathrm{Ti}(\mathrm{OEt})_{4}\right]$ was lyddrolyed by adding $0.5-0.7 \mathrm{M} \mathrm{H} \_\mathrm{O}$ dropwise. Ellanol was used as solvent to make these solutions and the reaction temperatures were adjusted in the range of $25-35^{\circ} \mathrm{C}$. The concentration of $\mathrm{H}_{2} \mathrm{O}$ was in excess compared to that of $\mathrm{Ti}(\mathrm{OE})_{4}$. Therefore the hydrolysis reaction was estimated to procecd in a pseudo-first order reaction. The UV absorbance of the solution was measured at a certain wavelength during the course of reaclion and its rate constant was calculated from the variation of UV absorbance with time. The warcIengith used to measure the absorbance was selected where the absorbance varied regularly: $310 \mathrm{~mm}$. which was $10 \mathrm{~mm}$ longer than the watelength of the maximum absorbance. $300 \mathrm{~mm}$. of $\mathrm{Ti}(\mathrm{OE})_{4}$ solution. The absorbance variations with time were measured in $\mathrm{H}_{2} \mathrm{O}$ concentrations ranging from $0.5 \mathrm{M}$ to $0.7 \mathrm{M}$ and at temperatures of $25^{\circ} \mathrm{C} .30^{\circ} \mathrm{C}$ and $35^{\circ} \mathrm{C}$. With these data. the rate constants of the pseudo-first order reaction $\left(k_{\mathrm{chl}}\right)$ were calculated by the following Guggenhcim cquation ${ }^{1 \cdot 1}$

$$
\ln \left(\mathrm{A}_{(++31}-\mathrm{A}_{1}\right)=-\boldsymbol{k}_{\text {olls }} \cdot t+\text { constants }
$$

Here. $A_{t}$ is the absorbance at $310 \mathrm{~nm}$. time 1 and $A_{t, 4 t}$ is the absolute cquilibrium absorbance which is an absorbance at a lime 2-3 times longer than the half-life.

\section{Results and Discussion}

The reaction is thought to be composed of two stages. One is a hydrolysis stage where Ti(OEt $)_{4}$ is lydrolyzed 10 form Ti-OH bonds. In this stage. UV absorbance of the solution increases gradually. The other stage is a condensation polymerization stage where Ti-O-Ti bonds form resulting in the creation of a threc-dimensional structure. which precipitates out of solution. In this stage. the absorbance increases quickly. This rapid increase in absorbance makes it very difficult to determine the absolute cquilibrium point of absorbance. Therefore. the hydrolysis reaction stage. where UV absorbance increases gradually. was used to deicrninic the reaction rate constant. The absorbance measured just before precipitation began was closen as the absolute equilibrium absorbance $\left(A_{t .11}\right)$ and the half-life $\left(t_{1}\right)$ ) was deternined using the above equilibrium absorbance.

Figure 1 shows the absorbance changes with time at various temperatures (a) and $\mathrm{H}_{2} \mathrm{O}$ concentrations (b). It carı be scen from Figure 1 that the absorbance (In $\left(A_{t}, A_{t}-A_{t}\right)$ ) varies linearly with lime at any iemperalures and $\mathrm{H}_{2} \mathrm{O}$ concentration. obcying Guggentcim's equation. This means that the absolute cquilibrium absorbance chosen above coincides with the Guggenheim's equilibrium absorbance. It is also confinned from Figure 1 that the slopes of the straight lines increase with increasing temperature (a) and $\mathrm{H}_{2} \mathrm{O}$ concentration (b). The slope of the straight line of absorbance clange corresponds to the 1st order reaction rate constant for the Ti $(\mathrm{OEt})_{\dashv}$ hydrolysis. $k_{\text {its. }}$. in the Guggenheim method. The increase in the slope. showed in Figure 1, indicates that the lst order rate constants increase with increasing temperature and $\mathrm{H}_{2} \mathrm{O}$ concentration. 

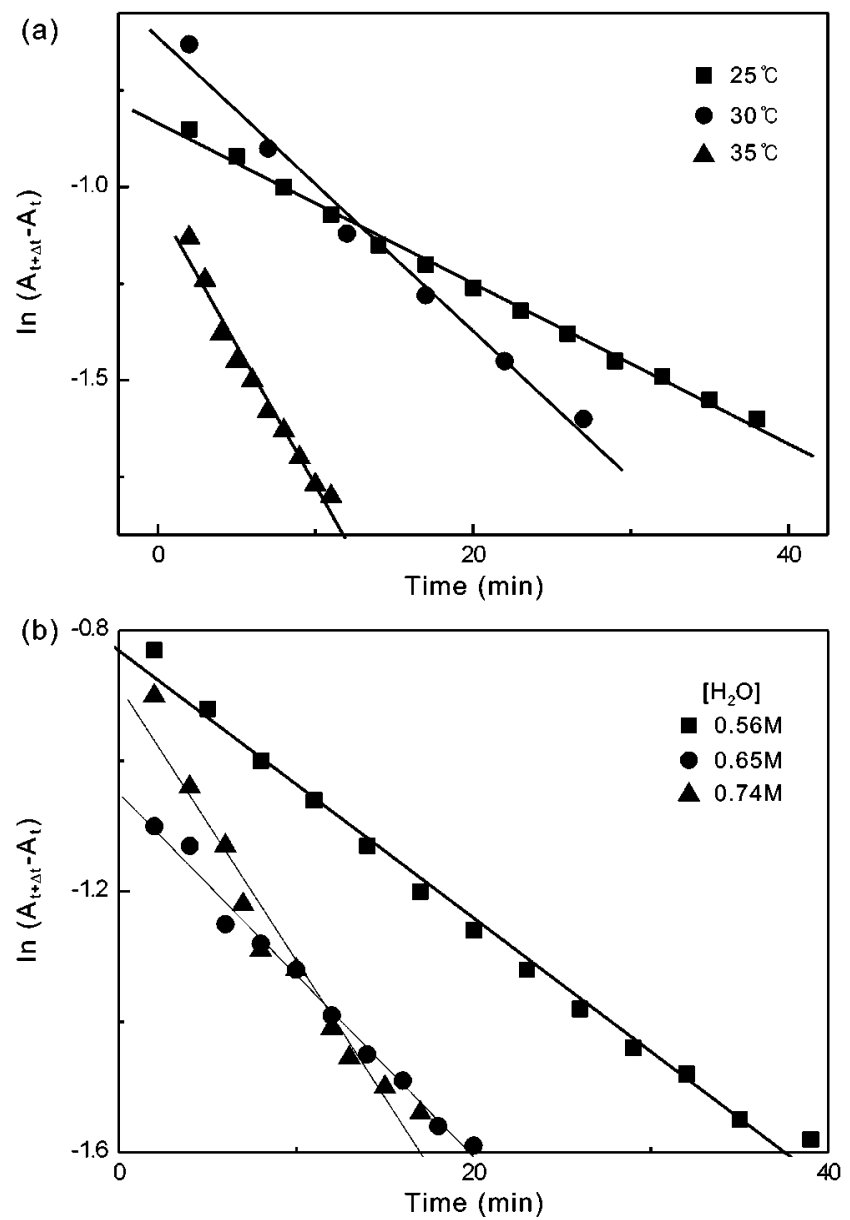

Figure 1. Plots of $\ln \left(\Lambda_{1} \cdot 3_{1}-\Lambda_{1}\right)$ is time for the hydrolysis of Ti(OF.t) $)_{+}$at various temperatures $(a)$ and vatious concentration of $11: 0(b)$.

Kivinen ${ }^{15}$ explained the relationship between the rate constants and $\mathrm{H}_{2} \mathrm{O}$ concentrations in the following equation. with assumption that $n$ molecules of $\mathrm{H}_{2} \mathrm{O}$ participate in the initial hydroly sis reaction to form the transition state.

$$
\ln k_{\mathrm{u} \cdot \mathrm{s}}=n \cdot \ln \left[\mathrm{H}_{\mathbf{2}} \mathrm{O}+\ln k_{\mathrm{sp}}\right.
$$

By Kivinen's equation. a linear relationship exists between the log values of $\mathrm{H}_{2} \mathrm{O}$ concentration and rate constant of the pseudo-first order reaction. In this plot. the slope of a straight line indicates the number of $\mathrm{H}_{2} \mathrm{O}$ (n-ralue) which participates in the initial hydrolysis reaction and the intercept implies the second order rate constant $\left(k_{\text {exp }}\right)$. In addition Kivinen interpreted the reaction to proceed via a bimolecular path when the slopes of the straight line. $n$-value, were 2-3. while in the case of $n$-value of 6-7. the reaction occurred wa a unimolecular path. ${ }^{1.5}$

The plot of Kivinen's equation for the hydrolysis of $\mathrm{Ti}(\mathrm{OEt})_{\dashv}$ is shown in Figure 2. This plot gives straight lines at various temperatures and we can estimate that the hydrolysis of $\mathrm{Ti}(\mathrm{OEt})_{4}$ obeys Kivinen's equation. Moreover. it can be seen from Figure 2 that the slope of the straight lines. the numbers of $\mathrm{H}_{2} \mathrm{O}$ molecules (n). increase with increasing temperature. $n$-ralues calculated from the slopes

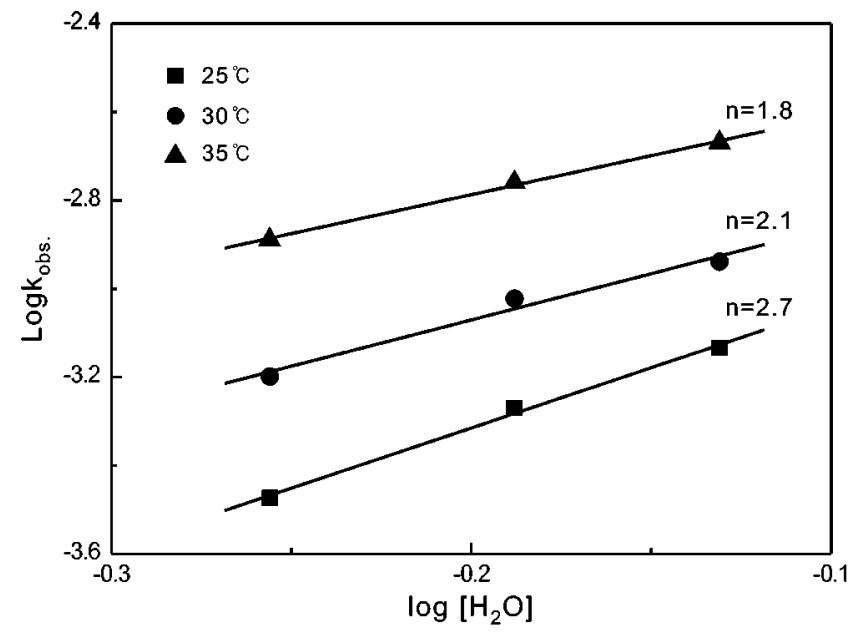

Figure 2. Plots of $\log \left[\mathrm{H}_{2} \mathrm{O}\right]$ vs. $\log k_{\text {obs. }}$. for the hydrolysis of $\mathrm{Li}(\mathrm{OL})$ ), at various temperatures ( $n$ : the number of $\mathrm{H}_{2} \mathrm{O}$ molecules).

of the straight lines in Figure 2 were 1.8-2.7. The second order rate constants. $\boldsymbol{k}_{\text {s.p. }}$ were also deternined from the intercept of straight lines. By Kivinen's n-value criterion. the reaction path to the transition state for the hydrolysis of $\mathrm{Ti}(\mathrm{OEt})_{1}$ is bimolecular from the above $n$-values. The temperature dependence of the rate constant can be discussed using the well known Arrhenius equation $(\ln k=\ln .1-$ $\left(E_{a} / R T\right)$ ). This equation was applied to the temperature dependence of the second order rate constant, $k_{\text {esp. }}$ for the hydrolysis of $\operatorname{Ti}(\mathrm{OEt})_{1}$ and the activation energy $\left(E_{0}\right)$ was calculated from slope of the straight line in the $\ln k_{\mathrm{cop}}$ is. $1 / \mathrm{T}$ plot. Activation enthalpy $\left(\Delta I^{+}\right)$and activation entropy $\left(\Delta S^{+}\right)$ were also determinded by the transition state theory using the calculated activation energy $\left(E_{u}\right)$.

In general, the mechanism of ligand substitution through the bimolecular reaction path depends on the behavior of the leaving group and entering group ${ }^{16-2 i}$ Two kinds of mechanisms have been proposed. One is an associative (A) mechanism in which entry of the entering group occurs first. then a detectable intermediate of expanded coordination number is formed. The other mechanism is an interchange associative $\left(l_{a}\right)$ mechanism in which the transition state is reached mostly through formation of the bond of the entering group. In this mechanism, however the character of the dissociative (D) mechanism is comprised. so that bond weakening of the leaving group also takes place to a certain extent in the course of reaching the transition state. Two

Table 1. $\Delta H^{+}=\Delta S^{+}$and $n$-values for the hydrolysis of some litanim alkoxides (at $298.15 \mathrm{~K}$ )

\begin{tabular}{|c|c|c|c|c|}
\hline & $\begin{array}{c}\Delta I^{+} \\
\text {(k.Itrnol) }\end{array}$ & $\begin{array}{c}\Delta S^{+} \\
(k \cdot I m o l \cdot K)\end{array}$ & $\begin{array}{c}-\mathrm{T} \Delta S^{+} \\
(\mathrm{k} \cdot \mathrm{Imol})\end{array}$ & $n$-values \\
\hline $\mathrm{Ti}(\mathrm{OCF}: \mathrm{t})_{4}{ }^{a}$ & 56.1 & $-110 \times 10^{-3}$ & 32.8 & 2.7 \\
\hline $\operatorname{Ti}\left(\mathrm{C}^{r} \mathrm{Pr}\right)_{4}{ }^{11}$ & 58.2 & $-8.3 .7 \times 10^{-5}$ & 24.9 & 3.1 \\
\hline $\operatorname{Tic}\left(\left(^{\prime 3} \mathrm{Pr}\right)_{+}^{1 / 2}\right.$ & 25.5 & $-2.33 \times 10^{-2}$ & 69.5 & 3.4 \\
\hline $\left.\operatorname{Tic}\left(0^{\prime \prime}\right] 3 t\right)_{4}{ }^{1:}$ & 19.7 & $-207 \times 10^{-3}$ & 61.7 & 4.8 \\
\hline
\end{tabular}

athis work. 


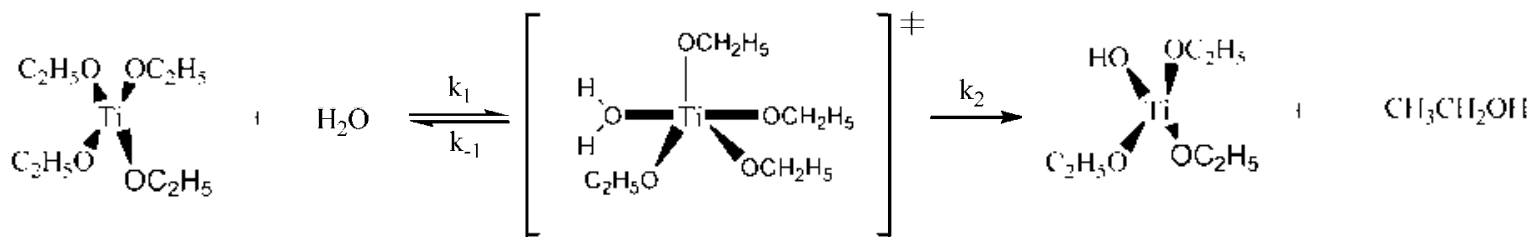

Associative(A) mechanism

Figure 3. Proposed scheme of hydrolysis reaction mechanism for Ti(OFt)

terms that are components of activation free energy $\left(\Delta G^{\dagger}\right)$. activation enthalpy $\left(\Delta I^{+}\right)$and entropy $\left(-\mathrm{T} \Delta S^{+}\right)$, are thought to be related to the bond weakening of leaving group and the bond fonning of entering group respectively: A high value for the activation enthalpy is associated with the difficulty of bond weakening of the leaving group, and a large activation entropy indicates that the bond for the entering group is formed with ease. $\Delta I^{+} .-\mathrm{T} \Delta S^{+}$and $n$-values for the lyddrolysis of some titanium alkoxides are given in Table $1^{11-1.3}$ In the case of $\operatorname{Ti}\left(\mathrm{O}^{t} \mathrm{Pr}\right)_{4}$ and $\operatorname{Ti}\left(\mathrm{O}^{\prime \prime} \mathrm{Bt}\right)_{4}$, it is obvious from Table 1 that $-\mathrm{T} \Delta S^{+}$values are much larger than $\Delta I^{+}$ values indicating that the bonds for the entering groups were easily formed. Moreover it can be seen from the small value of $\mathrm{NI}^{+}$that bond weakening of the leaving group also occurred in the path of transition state. Consequently, the transition states of the lydroly sis for $\operatorname{Ti}\left(\mathrm{O}^{n} \mathrm{Pr}\right)_{1}$ and $\operatorname{Ti}\left(\mathrm{O}^{n} \mathrm{Bt}\right)_{1}$ were reached through the interchange associative $\left(l_{i}\right)$ mechanism described above.

However. $\Delta I^{+}$of $\mathrm{Ti}\left(\mathrm{O}^{\prime} \mathrm{Pr}\right)_{4}$ in Table $\mathrm{l}$ is larger than $-T \Delta S^{+}$. which is opposite of what was observed for $\mathrm{Ti}\left(\mathrm{O}^{n} \mathrm{Pr}\right)_{4}$ and $\mathrm{Ti}\left(\mathrm{O}^{\prime \prime} \mathrm{Bt}\right)_{4}$. We concluded in our previous work that the transition state of $\mathrm{Ti}\left(\mathrm{O}^{i} \mathrm{Pr}\right)_{4}$ hydrolysis was reached is the associative (A) mechanism in which a detectable intermediate with a coordination number of five was formed without bond weakening of the leaving group. In our present work for Ti(OEt), hydrolysis. $\Delta I^{+}(56.1 \mathrm{~kJ} / \mathrm{mol})$ shows a similar value to that of $\operatorname{Ti}\left(\mathrm{O}^{i} \mathrm{Pr}\right)_{4}(58.2 \mathrm{~kJ} / \mathrm{mol})$ and also. $-\mathrm{T} \Delta S^{+}(32.8 \mathrm{~kJ} / \mathrm{mol})$ is less than $\Delta H^{+}$as in the case of $\mathrm{Ti}\left(\mathrm{O}^{\prime} \mathrm{Pr}\right)_{\text {. }}$. According to these results, it is proposed that an associative (A) mechanism is most appropriate for the hydrolysis of $\mathrm{Ti}(\mathrm{OEt})_{+}$(Figure 3 ).

\section{References}

1. T.ivage, J. Chemical processing of Cenmics: I ce. B. I., Ed.: Marcel Dekker Ine: Nen York. U. S. A.. 19\%4: chap. 1.

2. Brinker. C. J.: Scherer. G, W, Sol-rel Scionce: Academic l'ress: New York. U. S. A.. 1990: clap. 2.

3. Jivage, J.: I Ientr. M.: Sanchez, C. Irogg, Solid Sink Chem. 1988. 18, 259

4. Sakia, S. Sol-Gel Science; Watanabe, M. T.d: Agneshouho: Japan. 1988: 4

5. Minato. H. Bull. Chem Soc.Japan 1964.37. 316.

6. Hartel. R. W. Berglund. K. A Mater Res. Soc. 1986. 73. 633.

7. Babonncau, F.: I.caustic. A.: I ivage J. Hater Res. Soc: 1988. 121. 317

8. Docutt. S.: Hetrry, M.: Sanchez. C.: I.ivage, I. J. Non-Cnst. Solids 1987.89.206.

9. Assink. R. A.: Kay. B. D, Mater Res. Soc 1988. 12/. 25.

10. P'ouxviel. J. C.: Boilot. J. P?: Beloeil. J. C.: Lallemand. J. P.J. WonCovt solids 1987.89.345.

11. Miung. I. I.: Chung. Y. S.: Krong J. B.: Kim. H. K. J. of Konem Ind \& Eng. Chemishy 1996, 7(4),794

12. Myung. J. I.: Park. J. K.: Chung. Y. S.: Kyong. I. B.: Kim. H. K. ihid $1997.8(5) .777$.

13. P'urk. J. K.: Myung. J. J.: Chenng. Y. S.: KYone. J. B.: Kim. H. K.J. Koman Chem Soc. 1998. 22.281

14. Guggenheim, F. A. Phit. Nag. 1926, 2,538

15. Kivinct. A. Acta Chem. Sctmd 1965. 19.845

16. Iluheev. I. Г.: Keiter. F. A.; Keiter. R. I. Inorg. Chem. Janc. P.. Ed.: HarperCollins: New York. U. S. A.. 1993: p 540.

17. Hudson. R. F. Ber Bunsenges Physic. Chem. 1964. 68. 215.

18. Kim. Y. C.: Lim. I. W.: Choi. S. Y.: Kim. S. K. J. Norean (hthe Soc: 1999. $+3,1,15$

19. Kondo. Y.: Olnishi, M. Bu/l. Chem. Soc Japan 1972. 45. 3579

20. Matsui. T.: Tokura. N. Bull. ('hem. Soc. Japat 1970. to. 1751 